\title{
HEGEL AND THE SPIRIT
}





\title{
HEGEL AND THE SPIRIT
}

\section{PHILOSOPHY AS PNEUMATOLOGY}

\author{
Alan M. Olson
}

PRINCETON UNIVERSITY PRESS

PRINCETON, NEW JERSEY 
COPYRIGHT $\odot 1992$ BY PRINCETON UNIVERSITY PRESS

PUBLISHED BY PRINCETON UNIVERSITY PRESS, 41 WILLIAM STREET,

PRINCETON, NEW JERSEY 08540

IN THE UNITED KINGDOM: PRINCETON UNIVERSITY PRESS, OXFORD

ALL RIGHTS RESERVED

LIBRARY OF CONGRESS CATALOGING-IN-PUBLICATION DATA

OLSON, ALAN M.

HEGEL AND THE SPIRIT : PHILOSOPHY AS PNEUMATOLOGY / ALAN M. OLSON.

P. CM.

INCLUDES BIBLIOGRAPHICAL REFERENCES AND INDEX.

ISBN 0-691-07411-9 (HARD) ISBN: 978-0-691-14669-0

1. HEGEL, GEORG WILHELM FRIEDRICH, 1770-1831. 2. SPIRIT-

HISTORY-19TH CENTURY. I. TITLE.

B2949.S75047 $1992 \quad 193-D C 20 \quad 91-41996 \quad$ CIP

THIS BOOK HAS BEEN COMPOSED IN LINOTRON BASKERVILLE

PRINCETON UNIVERSITY PRESS BOOKS ARE PRINTED ON ACID-FREE PAPER, AND MEET THE GUIDELINES FOR PERMANENCE AND DURABILITY OF THE COMMITTEE ON PRODUCTION GUIDELINES FOR BOOK LONGEVITY OF THE COUNCIL ON LIBRARY RESOURCES

PRINTED IN THE UNITED STATES OF AMERICA

$\begin{array}{llllllllll}1 & 3 & 5 & 7 & 9 & 10 & 8 & 6 & 4 & 2\end{array}$ 
For Janet, Maren, and Sonja 

The Holy Spirit is, in fact, the one wholly credible and indubitable member of the Divine Trinity. Even if we doubt the existence of the sources from which it is alleged to proceed, a doubt which, in our twilight state, cannot but afflict us at every moment of our life, we cannot yet doubt its living presence within us, above all when we fall short of our higher aspirations, but also when it confers upon us the guidance, strength, peace, and joy that it at times does.

(John N. Findlay, "Thoughts Regarding the Holy Spirit") 
